\title{
Meningkatkan keterampilan procedural dan keterampilan berpikir tinggi mahasiswa melalui model pemecahan masalah pada perkuliahan elektronika dasar
}

\author{
Tursina Ratu ${ }^{1}$, Muhammad Erfan ${ }^{1}$ \\ ${ }^{1}$ Prodi Pendidikan Fisika, Universitas Samawa, Kabupaten Sumbawa 84371, Indonesia. \\ E-mail: tursinaratu@universitassamawa.ac.id; muhammaderfan@universitassamawa.ac.id
}

Received: 0201 2018. Revisied: 2901 2018. Accepted: 02032018

\begin{abstract}
Abstrak
Berlakunya Kerangka Kualifikasi Nasional Indonesia (KKNI) mengharuskan jenjang Sarjana memiliki kompetensi lulusan mencakup pengetahuan, keterampilan dan sikap. Standar ini secara tidak langsung menghendaki mahasiswa untuk memiliki keterampilan berpikir tingkat tinggi dalam menyelesaikan permasalahan, khususnya Elektronika Dasar. Elektronika Dasar adalah mata kuliah dengan konsep dasar fisika yang mengedepankan kemampuan analisis sintesis. Oleh karena itu, Penelitian ini bertujuan untuk meningkatkan keterampilan prosedural dan keterampilan berpikir tingkat tinggi melalui model pemecahan masalah. Jenis penelitian yang digunakan berupa penelitian tindakan kelas dengan teknik pengambilan data meliputi lembar observasi dan tes. Hasil Penelitian menunjukkan bahwa pembelajaran Elektronika Dasar dengan model pemecahan masalah dapat meningkatkan keterampilan prosedural dan keterampilan berpikir tingkat tinggi terlebih pada ranah analisis dan sintesis mahasiswa Program Studi Pendidikan Fisika FKIP Universitas Samawa pada perkuliahan Elektronika Dasar.
\end{abstract}

Kata Kunci: kemampuan analisis; sintesis; pemecahan masalah; elektronika dasar

\section{Improving Student's Procedural Skills and Higher Order Thinking Skills of Students Through Problem-Solving Models In Basic Electronics Courses}

\begin{abstract}
The enforcement of the Indonesian National Qualification Framework requires that Bachelor's degree graduate competencies include knowledge, skills and attitudes. This standard requires students to have Higher Order Thinking Skills (HOTS) in solving problems, especially basic electronics. Basic electronics is a subject with basic concepts of physics that emphasizes the ability of synthesis and analysis. Therefore, this research aim are to improve procedural skill and higher order thinking skill of students trough problem solving model. The type of research used in the form of Classroom Action Research with data retrieval techniques by observation and test sheets. The results showed that learning with problem-solving model can improve procedural skills, and high-order thinking skill especially in analysis and synthesis of students of Physics Education Study Program, University of Samawa on Basic Electronic course.
\end{abstract}

Keywords: student's analysis ability; synthesis; problem solving; basic electronics

\section{PENDAHULUAN}

Usaha sadar yang dilakukan oleh pemerintah dalam meningkatkan sumber daya manusia yang berkualitas secara cerdas, kreatif dan mampu bersaing dengan negara- negara lain. Usaha ini terlihat dengan adanya perbaikan sistem pendidikan di Indonesia. Pemerintah memperbaiki sistem pendidikan melalui perubahan kurikulum. Perubahan kurikulum perguruan tinggi merupakan perubahan pada seperangkat rencana, tujuan, 


\section{Jurnal Pendidikan Fisika dan Keilmuan (JPFK), 4 (1), 2018 - 31}

Tursina Ratu, Muhammad Erfan

isi dan bahan ajar yang pada akhirnya akan menentukan pencapaian tujuan pendidikan yang diinginkan.

Kurikulum perguruan tinggi yang berlaku di Indonesia saat ini adalah Kerangka Kualifikasi Nasional Indonesia (KKNI). KKNI memiliki standar kompetensi lulusan yang mencakup sikap, pengetahuan, keterampilan umum dan keterampilan khusus. Pembelajaran fisika berdasarkan KKNI menggunakan pendekatan saintifik, yang terdiri dari mengamati (observing), menanya (questioning), menalar (associating), melakukan (experimenting) dan mengkomunikasikan (networking) (Permendikbud RI No. 73 tahun 2013).

Berlakunya kurikulum KKNI di Indonesia dalam capaian pembelajaran menuntut kemampuan dosen terhadap pengetahuan, keterampilan, kompetensi, dan akumulasi pengalaman kerja. Untuk mencapai hal tersebut, perencanaan proses pembelajaran dirancang dalam bentuk Rencana Pembelajaran Semester (RPS), penilaian proses pembelajaran menggunakan pendekatan penilaian otentik yang menilai kesiapan proses dan hasil belajar mahasiswa secara utuh tanpa mengabaikan program pengayaan atau lebih dikenal dengan Semester Pendek (SP) (Permendikbud RI No. 49 tahun 2014). Implementasi KKNI akan sesuai harapan jika dosen mampu menyusun RPS, memahami konsep penilaian otentik dan melaksanakannya dalam pembelajaran. Dalam hal ini, mata kuliah merupakan alat untuk melatih mahasiswa memiliki keterampilan berpikir.

Salah satu mata kuliah yang menggunakan keterampilan berpikir adalah Elektronika Dasar. Melalui mata kuliah Elektronika Dasar, mahasiswa tidak hanya dituntut memiliki kemampuan matematis saja, melainkan juga konsep fisika. Kondisi ini menunjukkan bahwa mahasiswa harus memiliki kemampuan berpikir yang kompleks. Keterampilan berpikir yang dikembangkan dan sesuai dengan KKNI adalah HOTS. HOTS melalui sains meliputi keterampilan berpikir kritis, berpikir kreatif dan pemecahan masalah (Hamalik, 2014). Ketiga keterampilan tersebut saling berhubungan satu sama lain yang merupakan bagian dari HOTS. Melatih HOTS pada mahasiswa, memerlukan model pembelajaran yang berpusat pada mahasiswa sebagai peserta didik. Dengan demikian, mahasiswa memiliki pengalaman sendri dalam mengembangkan kemampuan berpikir.

Elektronika Dasar merupakan salah satu mata kuliah yang memiliki konsep dasar fisika yang mengedepankan kemampuan analisis dan sintesis, khususnya pada materi rangkaian listrik. Materi kelistrikan merupakan salah satu cabang ilmu fisika yang dalam pembelajarannya menekankan pada pendekatan kualitatif (Zacharia \& Jong, 2014). Penekanan terhadap pendekatan kualitatif dikarenakan kemampuan mahasiswa dalam membaca dan menganalisis rangkaian merupakan bagian penting dalam pembelajaran kelistrikan (Wahyudi, 2015). Terlebih, pembelajaran kelistrikan memiliki peranan penting dalam kehidupan sehari-hari.

Hasil analisis butir soal (pretest) menunjukkan bahwa mahasiswa hanya mampu menyelesaikan soal rangkaian listrik yang berkisar pada aspek mengingat, memahami dan menerapkan. Dengan kata lain, mahasiswa cenderung memiliki keterampilan berpikir tingkat rendah dalam menyelesaikan soal yang diberikan. Hal ini berbanding terbalik dengan tuntutan standar pencapaian pada materi Elektronika Dasar yang memerlukan kemampuan analisis dan sintesis dalam menyelesaikan rangkaian listrik. Kemampuan analisis dan sintesis merupakan bagian dari aspek HOTS. Oleh karena itu, diperlukan sebuah solusi untuk mengatasi permasalahan tersebut.

Analisis rangkaian listrik merupakan salah satu materi pokok yang wajib dikuasai mahasiswa Program Studi Pendidikan Fisika FKIP Universitas Samawa pada mata kuliah Elektronika Dasar. Rangkaian listrik (rangkaian elektrik) merupakan interkoneksi berbagai piranti (divais - device) yang secara bersama melaksanakan suatu tugas tertentu (Sudirham, 2012). Tugas tertentu dapat diartikan sebagai suatu proses informasi ataupun energi. Informasi ataupun energi ini dikonversikan ke dalam sinyal listrik melalui rangkaian listrik. Bentuk sinyal inilah nanti yang dapat disalurkan dengan mudah ke piranti tertentu.

Dalam mempelajari perilaku suatu rangkaian listrik, kita melakukan analisis rangkaian listrik. Menganalisis rangkaian listrik membutuhkan kemampuan analisis dan sintesis. Dalam menganalisis rangkaian 


\section{Jurnal Pendidikan Fisika dan Keilmuan (JPFK), 4 (1), 2018 - 32}

Tursina Ratu, Muhammad Erfan

listrik, hal-hal dasar yang perlu diperhatikan adalah: struktur dasar rangkaian, besaranbesaran listrik, peristiwa transien, serta landasan dalam melakukan analisis seperti hukum-hukum rangkaian (Hukum Ohm, Hukum Kirchhoff, dsb), kaidah-kaidah rangkaian, teorema rangkaian (Teorema Thévenin, Teorema Norton, dsb), serta metoda-metoda analisis rangkaian listrik.

Materi analisis rangkaian listrik bersifat abstrak, sehingga diperlukan HOTS dalam mengembangkan kemampuan berpikir mahasiswa dalam mempelajarinya. Kemampuan analisis dan sintesis merupakan bagian dari HOTS.

Kemampuan analisis merupakan kemampuan memisahkan definisi operasional menjadi beberapa kelompok terkecil ditinjau dari hubungan dan kesesuaian antar komponen tersebut sehingga lebih mudah untuk dipahami (Anderson \& Krathwohl, 2010). Untuk memiliki kemampuan awal dalam berpikir tingkat tinggi, maka mahasiswa harus memiliki kemampuan analisis.

Kemampuan sintesis adalah kemampuan untuk menggabungkan komponen-komponen terkecil menjadi sebuah pola struktur baru yang bersifat menyeluruh dengan berdasar pada jenjang pengetahuan, pertanyaan dan jawaban
(Anderson \& Krathwohl, 2010). Untuk memiliki kemampuan ini, mahasiswa harus memiliki kreativitas dalam menggabung informasi-informasi yang baru diperoleh (data mentah) menjadi sebuah struktur organisasi yang lebih mudah dipahami dan telah dibuktikan kebenarannya melalui fakta atau prinsip pengetahuan yang ada.

Materi menganalisis rangkaian listrik lebih ditekankan pada kemampuan mahasiswa dalam hal mengenali berbagai komponen listrik, mengetahui berbagai fungsi piranti dan rangkaian kelistrikan melalui kemampuan menganalisis dan mensintesis dalam menyelesaikan masalah.

Pemecahan Masalah adalah suatu proses mental dan intelektual dalam menemukan masalah dan memecahkan berdasarkan data dan informasi yang akurat, sehingga dapat diambil kesimpulan yang tepat dan cermat (Hamalik, 2004). Model Pemecahan Masalah dirancang dengan menempatkan mahasiswa untuk berpikir mandiri. Mahasiswa diberikan sebuah kasus atau permasalahan dan diberi kesempatan untuk memecahkan masalah itu sendiri selama proses pembelajaran berlangsung.

Tahap-tahap pada model pemecahan masalah disajikan pada tabel 1 berikut.

Tabel 1. Tahap-Tahap Pengajaran dengan Model Pemecahan Masalah (Modifikasi dari Faiq, 2012)

\begin{tabular}{|c|c|c|}
\hline No & Tahap & Peran Dosen \\
\hline 1 & $\begin{array}{l}\text { Menyampaikan tujuan dan } \\
\text { mempersiapkan mahasiswa }\end{array}$ & $\begin{array}{l}\text { Dosen menjelaskan tujuan pembelajaran, sasaran yang harus } \\
\text { dicapai oleh mahasiswa, memotivasi dan mempersiapkan } \\
\text { mahasiswa dalam kegiatan pembelajaran berbasis pemecahan } \\
\text { masalah }\end{array}$ \\
\hline 2 & $\begin{array}{l}\text { Mendemonstrasikan keterampilan } \\
\text { (pengetahuan prosedural) atau } \\
\text { mempresentasikan pengetahuan } \\
\text { (deklaratif) }\end{array}$ & $\begin{array}{l}\text { Dosen mendemonstrasikan pengetahuan deklaratif dengan cara } \\
\text { menjelaskan konsep rangkaian listrik dengan mengaitkan } \\
\text { penerapan rangkaian listrik dalam kehidupan sehari-hari serta } \\
\text { mendemonstrasikan keterampilan prosedural dengan cara } \\
\text { menyajikan masalah dalam bentuk soal latihan selanjutnya dosen } \\
\text { mengajarkan cara untuk menyelesaikan masalah secara bertahap, } \\
\text { seperti mengklasifikasikan dan mengorganisasikan masalah, } \\
\text { menyusun rumusan penyelesaian yang sesuai untuk memecahkan } \\
\text { masalah tersebut. }\end{array}$ \\
\hline 3 & Membimbing pelatihan & $\begin{array}{l}\text { Dosen memberi dorongan dan bimbingan (pelatihan) dalam } \\
\text { menyelesaikan masalah baru seperti tahap sebelumnya. }\end{array}$ \\
\hline 4 & $\begin{array}{l}\text { Mengecek pemahaman } \\
\text { (menganalisa) dan memberikan } \\
\text { umpan balik (mengevaluasi) }\end{array}$ & $\begin{array}{l}\text { Dosen menguji pemahaman mahasiswa dengan memberikan } \\
\text { sebuah permasalahan baru dan selanjutnya memberikan } \\
\text { pertanyaan umpan balik seperti yang telah dilakukan pada tahap } \\
\text { sebelumnya (tahap 2) }\end{array}$ \\
\hline 5 & $\begin{array}{l}\text { Memberikan pelatihan lanjutan } \\
\text { dan penerapan }\end{array}$ & $\begin{array}{l}\text { Dosen menyajikan permasalahan yang berbeda dari sebelumnya } \\
\text { namun serupa dengan tahap } 2 \text { dan } 3\end{array}$ \\
\hline
\end{tabular}





\section{Jurnal Pendidikan Fisika dan Keilmuan (JPFK), 4 (1), 2018 - 33}

Tursina Ratu, Muhammad Erfan

Penggunaan model pemecahan masalah diharapkan dapat membantu mahasiswa dalam menemukan solusi dengan tahapan tertentu. Mahasiswa juga diharapkan memiliki pengalaman sendiri dalam hal mengembangkan kemampuan proseduralnya sebagaimana hasil penelitian yang dilakukan oleh Hijrawati, Khaerudin \& Nurlila (2015) yang menyatakan bahwa penerapan model pemecahan masalah dalam proses pembelajaran fisika dapat meningkatkan hasil belajar siswa.

\section{METODE}

Jenis penelitian yang digunakan dalam penelitian ini adalah Penelitian Tindakan kelas (PTK) dengan model Hopkins (Arikunto, 2008). Penelitian ini dilakukan untuk mengatasi permasalahan rendahnya kemampuan berpikir mahasiswa Pendidikan Fisika FKIP Universitas Samawa terkait kemampuan analisis dan sintesis dalam menerapkan pengajaran langsung dengan menggunakan model pemecahan masalah.

Subjek penelitian adalah mahasiswa Pendidikan Fisika semester III FKIP Universitas Samawa dengan jumlah mahasiswa 17 Orang. Materi yang diajarkan yaitu rangkaian listrik yang terangkum dalam perkuliahan Elektronika Dasar dengan peneliti sebagai dosen yang mengajar. Teknik pengumpulan data yang digunakan dalam penelitian ini berupa tes.

Tes yang diberikan adalah pretest dan posttest dalam bentuk soal pilihan ganda beralasan. Pretest digunakan untuk mengetahui kemampuan analisis dan sintesis mahasiswa sebelum diberikan perlakuan. Posttest digunakan untuk mengetahui kemampuan analisis dan sintesis mahasiswa sesudah diberikan perlakuan (pengajaran dengan model pemecahan masalah).

Skor penilaian untuk butir soal pilihan ganda beralasan mengacu pada penskalaan tes yang disusun menjadi empat skor, seperti pada Tabel 2. Data yang telah diberi skor, dianalisis secara kuantitatif selanjutnya dikonversikan ke dalam bentuk pengkategorisasian. Pengkategorisasian ini bertujuan untuk mengkategorikan pencapaian kemampuan analisis dan sintesis mahasiswa dalam kategori rendah, sedang, dan tinggi, dengan tidak mengasumsi distribusi populasi yang normal.

\section{HASIL DAN PEMBAHASAN (70\%)}

\section{Analisis Pencapaian Keterampilan Prosedural}

Berdasarkan Tabel 2, Keterampilan prosedural pada siklus I yang diamati, diperoleh bahwa mahasiswa mengerjakan setiap prosedur sebesar $62,71 \%$ dengan kategori sedang. Kondisi ini menunjukkan bahwa masih ada beberapa mahasiswa yang belum paham dalam beberapa prosedur sehingga mendapat skor paling rendah. Pada siklus II, keterampilan prosedural mahasiswa lebih meningkat jika dibandingkan dengan siklus I. Keterampilan prosedural mahasiswa pada siklus II 72,55\%, dengan kategori tinggi. Hal ini menunjukkan bahwa mahasiswa memiliki peningkatan dalam mengerjakan setiap prosedur yang ada. Artinya, mahasiswa telah memiliki kemampuan prosedural yang baik.

Sejalan dengan pendapat Hunter (Nur, 2011) yang menyatakan bahwa pembelajaran langsung merupakan pembelajaran yang dirancang khusus untuk mengembangkan belajar mahasiswa sebagai peserta didik tentang pengetahuan deklaratif dan pengetahuan prosedural. Melalui model pemecahan masalah, mahasiswa difokuskan bukan pada apa yang mereka lakukan melainkan pada apa yang mereka pikirkan ketika diberi permasalahan. Dengan kata lain, Pembelajaranbdengan model pemecahan masalah dapat meningkatkan kemampuan prosedural mahasiswa dalam memecahkan sebuah masalah. Ketika mahasiswa aktif dalam memecahkan masalah, maka secara tidak langsung mahasiswa secara mandiri telah berlatih mengembangkan kemampuan berpikir analisis dan sintesisnya dalam memecahkan masalah. Kemampuan analisis dan sintesis merupakan bagian dari HOTS. 
Jurnal Pendidikan Fisika dan Keilmuan (JPFK), 4 (1), 2018 - 34

Tursina Ratu, Muhammad Erfan

Tabel 2. Hasil Capaian Keterampilan Prosedural dan Keterampilan Berpikir Tingkat Tinggi (HOTS)

\begin{tabular}{clcccc}
\hline \multirow{2}{*}{ No } & \multicolumn{1}{c}{ Aspek } & \multicolumn{2}{c}{ Siklus I } & \multicolumn{2}{c}{ Siklus II } \\
\cline { 3 - 5 } & & Persentase & Kategori & Persentase & Kategori \\
\hline 1 & Keterampilan Prosedural & $62,71 \%$ & Sedang & $72,55 \%$ & Tinggi \\
2 & $\begin{array}{l}\text { Keterampilan Berpikir Tingkat Tinggi } \\
\text { (HOTS) }\end{array}$ & $46,27 \%$ & Sedang & $65,23 \%$ & Tinggi \\
\hline
\end{tabular}

Analisis Pencapaian Keterampilan Berpikir tingkat Tinggi Sebelum dan Sesudah Diberi Perlakuan

Kemampuan awal mahasiswa terhadap kemampuan analisis dan sintesis sebelum diberikan perlakuan (pengajaran langsung dengan menggunakan model pemecahan masalah dapat diukur dengan memberikan pretest. Hasil pretest tersebut diketahui bahwa rata-rata kemampuan analisis dan sintesis mahasiswa sebesar $31,11 \%$ dengan kategori rendah. Hasil tersebut menunjukkan bahwa mahasiswa belum memiliki kemampuan analisis dan sintesis yang menggambarkan bahwa mahasiswa tersebut telah memiliki HOTS.

Rosnawati (2009) menyatakan bahwa untuk melatih HOTS pada mahasiswa sebagai peserta didik, memerlukan model pembelajaran yang berpusat kepada peserta didik, dan peserta didik mengetahui cara mengembangkan kemampuan berpikir. Artinya, mahasiswa dituntut untuk memiliki pengalaman berpikir secara secara mandiri dalam memecahkan masalah (fokus pada apa yang mereka pikirkan ketika diberi permasalahan). Untuk dapat memecahkan masalah mahasiswa harus memiliki kemampuan prosedural. Kemampuan prosedural dapat ditingkatkan melalui pengajaran dengan model pemecahan masalah.

Mahasiswa yang telah diberikan perlakuan berupa pengajaran dengan model pemecahan masalah menunjukkan hasil yang cukup berbeda. Hasil posttest pada siklus I, menunjukkan kemampuan analisis dan sintesis mahasiswa sebesar $46,27 \%$ dengan kategori sedang. Kondisi ini disebabkan mahasiswa baru memiliki pengalaman belajar dengan model pemecahan masalah terkait kemampuan analisis dan sintesis (dalam tahap adaptasi). Hasil posttest pada siklus II menunjukkan kemampuan mahasiswa mengalami peningkatan. Hal ini ditunjukkan dengan perolehan nilai sebesar 65,23\% dengan kategori tinggi. Artinya, mahasiswa memiliki kemampuan analisis dan sintesis yang baik setelah mendapat pengajaran dengan model pemecahan masalah.

Pengajaran dengan model pemecahan masalah terbukti dapat memberi pengaruh yang signifikan terhadap kemampuan analisis dan sintesis mahasiswa. Hal tersebut ditunjukkan dengan adanya peningkatan kemampuan analisis dan sintesis mahasiswa. Mahasiswa sebelum diberikan pengajaran dengan model pemecahan masalah memiliki kemampuan berpikir yang rendah. Namun, kemampuan analisis dan sintesis mahasiswa meningkat setelah diberikan pengajaran dengan model pemecahan masalah

\section{SIMPULAN}

Berdasarkan hasil dan pembahasan yang telah dipaparkan, diperoleh kesimpulan bahwa pembelajaran dengan model pemecahan masalah dapat meningkatkan keterampilan prosedural, dan keterampilan berpikir tingkat tinggi terlebih pada ranah analisis dan sintesis mahasiswa program studi Pendidikan Fisika FKIP Universitas Samawa pada mata kuliah Elektronika Dasar materi rangkaian listrik

\section{DAFTAR PUSTAKA}

Anderson, L. W \& Krathwohl, D. R. (2010). Kerangka Landasan untuk Pembelajaran, Pengajaran, dan Asesmen (Terjemahan Agung Prihantoro). New York: Addition Wesley Longman. (Buku Asli diterbitkan tahun 2001)

Arikunto, S.2008. Penelitian Tindakan Kelas. Jakarta: Bumi Aksara

Faiq, M., Cara Membuat Lembar Observasi : Contoh 1, 2012. Website: http:// penelitiantindakankelas.blogspot.co.i d/2012/05/cara-membuat-lembarobservasi-contoh-1.html, diakses tanggal 25 Juli 2017. 
Hamalik, O. 2004. Proses Belajar Mengajar. Jakarta: Bumi Aksara.

Hijrawati, Khaerudin \& Nurlila. Upaya Meningkatkan Hasil Belajar Fisika Melalui Model Pemecahan Masalah (Problem Solving) Pada Peserta

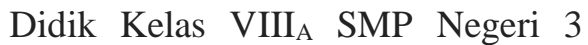
Sungguminasa. Jurnal Pendidikan Fisika Universitas Muhammadiyah Makassar. Vol 3. No. 3. 2015, pp. $270-278$.

Liliasari. 2009. Pengembangan Keterampilan Berpikir Tingkat Tinggi Siswa Sebagai Dampak Lesson Study, Jakarta: UPI.

Nur, M. 2011. Model Pengajaran Langsung. Surabaya: Unipress.

Peraturan Menteri Pendidikan dan Kebudayaan Republik Indonesia No. 73 tahun 2013

Peraturan Menteri Pendidikan dan Kebudayaan Republik Indonesia No. 49 tahun 2014

Rosnawati. 2009. Enam Tahapan Aktivitas Dalam Pembelajaran Matematika Untuk Mendayagunakan Berpikir Tingkat Tinggi Siswa (disampaikan dalam seminar nasional). Yogyakarta: UNY.

Sudirham, S. 2012. Analisis Rangkaian Listrik Jilid-1 (Rangkaian Arus
Searah dan Arus Bolak-Balik).

Darpublic, Kanayakan D-30

Bandung. http://www.darpublic.com, diakses tanggal 20 Juli 2017

Wahyudi. Analisis Hasil belajar Mahasiswa Pada pokok Bahasan Hukum Ohm dan Kircchoff Dalam Matakuliah Elektronika Dasar I. Jurnal Pendidikan Fisika dan Teknologi, vol 1, no 2, 2015, pp. 129 - 135.

Wardoyo, M. S. 2013. Pembelajaran Konstruktivisme Teori dan Aplikasi Pembelajaran dalam Pembentukan Karakter.Bandung: Alfabeta.

Zacharia, C. Z \& Jong, D.T., One Specific Advantage For Virtual Laboratories That May Support The Acquition Of Knowledge Is That Reality Can Be Adapted To Serve The learning Process, reality Can be Simplified By Taking Out Details. Cognition and Instruction, vol 32, no 2, 2014. pp. $101-158$.

Yusro, A. C. 2015. Pengembangan Modul Pembelajaran Fisika Berbasis Kontekstual Yang Terintegrasi Dengan Website Pada Siswa Kelas XI IA SMA Negeri 5 Madiun Tahun Ajaran 2012/2013 (Tesis, Universitas Sebelas Maret). 